\title{
Zosteriform molluscum contagiosum in an imunocompetent girl
}

\section{Selma El Kadiri, Hanane Baybay, Rhizlane Chaoui, Zakia Douhi, Sara Elloudi, Fatima Zahra Mernissi}

\author{
Department of Dermatology and Venerology, University Hospital Hassan II, Fez, Morocco
}

Corresponding author: Dr. Selma El Kadiri, E-mail: elkadiri-s@hotmail.com

Sir,

Molluscum contagiosum is a benign skin lesion with a characteristic appearance caused by cutaneous poxvirus infection [1]. Herein we report a case of a zosteriform eruption like molluscum contagiosum.

A 12-year-old girl who had a history of atopic dermatitis referred to our consultation for umbilicated pearly papules on the right side of the trunk for a l-month duration. She applied desonide $0.1 \%$ cream 15 days before for atopic dermatitis and developed lesions with a zosteriform distribution. Clinical examination revealed multiple, umbilicated, dome shaped papules lateralized to right side of trunk in a zosteriform pattern (Figs. la and lb). Histologic examination of skin biopsy showed lobules of hyperplastic squamous epithelium separated by fine septa of the compressed dermis and eosinophilic inclusion bodies above the basal cell layer. The patient was treated with curettage and topical application of $10 \%$ potassium hydroxide.

Molluscum contagiosum is a poxvirus infection caused by a virus in the subgenus Molluscipoxvirus with 4 viral subtypes. Clinically, it is characterized by solitary or multiple umbilicated, dome-shaped, waxy papules from 2 to $8 \mathrm{~mm}$ in diameter [1]. There is a predilection for the head, neck, trunk, flexural and genital areas in children and adolescents [2]. There have been reported cases of linear and koebnerization lesions in scar surgery [3]. The eruption of molluscum contagiosum lesions in our patient is probably associated with the application of desonide for atopic dermatitis. Since the altered epidermal barrier leads to increased susceptibility to viral skin infections and scratching leading to

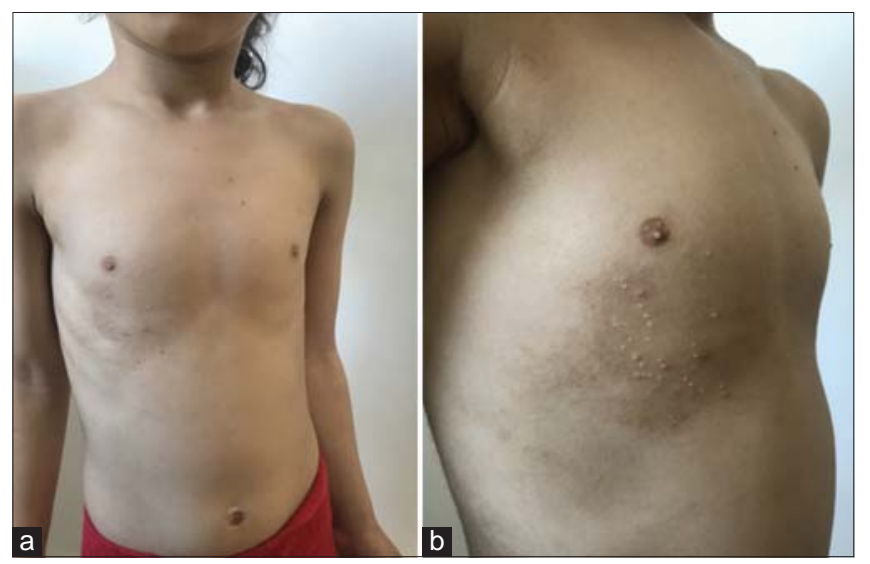

Figure 1: $(a$ and $b)$ Multiple, umbilcated, dome-shaped papules lateralized to right side of trunk

autoinoculation [1]. Zosteriform-like eruptions can be observed in several diseases, such as lichen planus, cutaneous metastasis, lymphangioma, and leishmaniasis.

To our knowledge, there is only one case of zosteriform molluscum contagiosum in the face in HIV patient [4]. Herein we report the first case of zosteriform molluscum contagiosum in an immunocompetent patient with atopic dermatitis.

\section{Consent}

The examination of the patient was conducted according to the Declaration of Helsinki principles.

The authors certify that they have obtained all appropriate patient consent forms. In the form the patient(s) has/have given his/her/ their consent for his/her/their images and other clinical information to be reported in the journal. The patients understand that their names and initials will not be published and due efforts will be made to conceal their identity, but anonymity cannot be guaranteed.

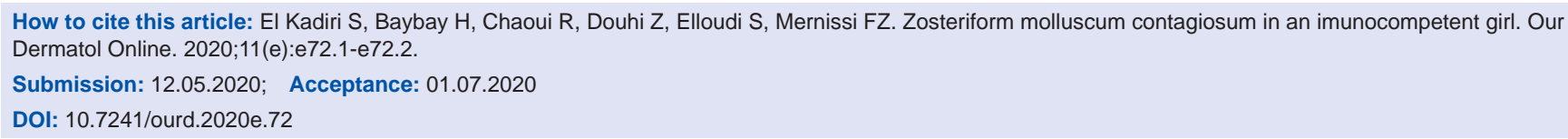


www.odermatol.com

\section{REFERENCES}

1. Damevska K, Emurlai A. Molluscum Contagiosum in a patient with atopic dermatitis. New Engl J Med. 2017;377:e30.

2. Elboukhari K, Achehboune K, Elloudi S, Baybay H, Mernissi FZ. A strange presentation of molluscum contagiosum in an immunocompetent child. Our Dermatol Online. 2020;11:212-3.

3. Flandeiro PT, Attard N. Koebnerized molluscum contagiosum. QJM. 2013;106:1043.
4. Borges-Costa J. Molluscum contagiosum infection presenting in a HIV patient as a zosteriform-like eruption. J Am Acad Dermat. 2012;66:AB131.

Copyright by Selma El Kadiri, et al. This is an open access article distributed under the terms of the Creative Commons Attribution License, which permits unrestricted use, distribution, and reproduction in any medium, provided the original author and source are credited.

Source of Support: Nil, Conflict of Interest: None declared. 